\title{
Understanding the electrocatalytic activity of transition metal nanoparticles for solid oxide cell fuel electrodes
}

\author{
Drasbæk, Daniel B.; Traulsen, Marie L.; Sudireddy, Bhaskar R.; Holtappels, Peter
}

Published in:

Electrochimica Acta

Link to article, DOI:

10.1016/j.electacta.2019.135004

Publication date:

2019

Document Version

Peer reviewed version

Link back to DTU Orbit

Citation (APA):

Drasbæk, D. B., Traulsen, M. L., Sudireddy, B. R., \& Holtappels, P. (2019). Understanding the electrocatalytic activity of transition metal nanoparticles for solid oxide cell fuel electrodes. Electrochimica Acta, 327, [135004]. https://doi.org/10.1016/j.electacta.2019.135004

\section{General rights}

Copyright and moral rights for the publications made accessible in the public portal are retained by the authors and/or other copyright owners and it is a condition of accessing publications that users recognise and abide by the legal requirements associated with these rights.

- Users may download and print one copy of any publication from the public portal for the purpose of private study or research.

- You may not further distribute the material or use it for any profit-making activity or commercial gain

- You may freely distribute the URL identifying the publication in the public portal 


\title{
Understanding the Electrocatalytic Activity of Transition Metal Nanoparticles for Solid Oxide Cell Fuel Electrodes
}

\author{
Daniel B. Drasbcek ${ }^{a}$, Marie L. Traulsen ${ }^{a}$, Bhaskar Reddy Sudireddy ${ }^{a}$, and Peter Holtappels ${ }^{a}$

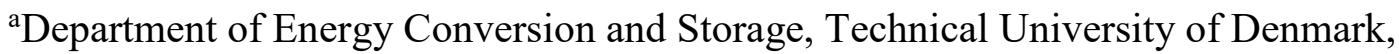 \\ Frederiksborgvej 399, 4000 Roskilde, Denmark
}

\section{Corresponding author}

Daniel Bøgh Drasbæk

E-mail: dadr@dtu.dk

Telephone: +4553547467

Address: Department of Energy Conversion and Storage, Frederiksborgvej 399, Building 228, Room S23. 4000 Roskilde, Denmark

\begin{abstract}
In this work, we utilized the concept of decoupling the electrocatalytic activity from the current conducting phase of solid oxide cell fuel electrodes to investigate the electrochemical performance of three different transition metals, namely $\mathrm{Ni}, \mathrm{Co}$, and Fe. It was found that the nickel and cobalt infiltrated cells had comparable performances in both $4 \% \mathrm{H}_{2} \mathrm{O} / \mathrm{H}_{2}$ and $50 \% \mathrm{H}_{2} \mathrm{O} / \mathrm{H}_{2}$. Furthermore, iron nanoparticles were found to be the better electrocatalyst at low $\mathrm{pO}_{2}$ values, however at higher $\mathrm{pO}_{2}$ values the iron infiltration became the inferior catalyst. Investigating the temperature dependence of the polarization resistance in terms of activation energy and pre-exponential factor showed interesting differences between the metal catalysts and a dependence on the gas atmosphere. The results were analyzed by developing a model based on the harmonic oscillator, the model allows for correlating changes in activation energy and pre-exponential factor with kinetic parameters of the electrode reaction. The model indicates that at higher $\mathrm{pO}_{2}$ values, iron
\end{abstract}


nanoparticles experience a surface blockade, i.e. strong bonding of the reactants to the catalytic sites. For the nickel electrocatalyst, an increase in steam content according to the model leads to an increase in the turnover frequency, which is in good agreement with earlier reports in literature.

\section{Keywords}

Solid Oxide Cells, Infiltration, Electrocatalytic Activity, Model for Adsorption of Species, Nanoparticles, Fuel Electrodes.

\section{Introduction}

Solid oxide cells (SOCs) are high-temperature electrochemical cells that offer a highly efficient conversion of chemically stored energy into electrical energy and reverse. The current state of the art (SoA) SOCs use a nickel-YSZ composite fuel electrode for $\mathrm{H}_{2} / \mathrm{H}_{2} \mathrm{O}$ and $\mathrm{CO} / \mathrm{CO}_{2}$ reactions [1]. However, the Ni-YSZ composite electrodes experience significant degradation during unintended redox cycles, are prone to carbon deposition and even small amounts of often seen impurities in the fuel, like sulphur, will inhibit the fuel electrode functionality [2-6]. These challenges with the $\mathrm{Ni} / \mathrm{YSZ}$ cermet electrodes can be circumvented by adding different external system components to the balance of plant, however, this will result in a more complicated system design and increase the system cost. Furthermore, enhanced stability of the fuel electrode is still needed since nickel particles tends to grow at the operating temperatures of the SOC, resulting in degradation in cell performance over time, due to loss of nickel percolation and loss of electrocatalytic active surface area [7]. Thus, alternatives to Ni- cermet electrodes and especially Ni-free fuel electrodes are still receiving considerable interest.

One strategy to overcome some of the challenges with the Ni/YSZ electrodes is to decouple the functionalities of the fuel electrode, by separating the electronically conductive phase from the 
electrocatalytic phase. This can increase the redox stability of the electrode, by designing a redox stable porous backbone that can be infiltrated with the electrocatalytic active material. This decoupling could be obtained by using donor-doped $\mathrm{SrTiO}_{3}$ (ST) compositions as backbone material, since these compositions are tolerant to oxygen, carbon, and sulphur containing atmospheres, have a high electronic conductivity and are highly redox stable [8-12]. It has already been found that the redox stability of the Nb-doped strontium titanate (STN) based SOC fuel electrodes is significantly enhanced compared to the conventional fuel electrode Ni/YSZ materials, even if the infiltrated electrocatalyst is nickel nanoparticles [13]. This is due to the fact, that the electronic conductivity in the infiltrated STN electrode is independent of the electrocatalyst. Nevertheless, new challenges arise with infiltrated STN electrodes, since the infiltrated nanoparticles will experience growth, which will decrease the triple phase boundary [14], just as the low ionic conductivity of the STN backbones makes co-infiltration with an ionic conductive phase advantageous.

In previous work performed by $\mathrm{T}$. Ramos et al., it was found that co-infiltrating a $\mathrm{Sr}_{0.94} \mathrm{Ti}_{0.9} \mathrm{Nb}_{0.1} \mathrm{O}_{3}$ (STN94)/YSZ cell with metals (Ni, Pd, and Ru) and gadolinium doped cerium oxide (CGO) increased the performance and stability of the SOC fuel electrode compared to the conventional $\mathrm{Ni} /$ YSZ [15-16]. However, both ruthenium and palladium are precious metals and therefore not suited for commercial use, due to their cost. Hence, it is of interest to explore the electrocatalytic activity of different, non-precious, transition metals which are infiltrated into the STN backbone structure. It is found in the literature that transition metals like nickel, cobalt, and iron will have comparable electrocatalytic behavior [16-17], but still shows interesting similarities and differences in electrocatalytic activity [18]. 
In the present work these three transition metals were infiltrated into STN94/YSZ symmetrical cells. In order to investigate the electrocatalytic activity of the transition metals alone, it was chosen to perform the infiltration without co-infiltration of CGO. The scope of the current work is to use electrochemical impedance spectroscopy to investigate and understand the electrocatalytic properties of nickel, cobalt, and iron nanoparticles. Furthermore, for analyzing the kinetics of the electrochemical reactions a model based on the harmonic oscillator is derived and applied on the experimental results.

\section{Experimental}

\subsection{Symmetrical cell fabrication}

The electrochemical characterization of the infiltrated electrocatalysts was made using symmetrical cells. For fabrication of the cells, STN94 ink was spray deposited onto a pre-sintered $240 \pm 10 \mu \mathrm{m}$ thick $\mathrm{Sc}_{2} \mathrm{O}_{3}, \mathrm{Y}_{2} \mathrm{O}_{3}$ co-stabilized $\mathrm{ZrO}_{2}$ (Sc-YSZ) electrolyte. After deposition, the electrodes were sintered at $1200^{\circ} \mathrm{C}, 8 \mathrm{~h}$ in air, resulting in electrode thicknesses between 20 and 40 $\mu \mathrm{m}$. A detailed description of the fabrication procedure of the symmetrical cells can be found elsewhere [9]. After sintering, the cells were laser cut into smaller pieces of $0.6 \mathrm{~cm} \times 0.6 \mathrm{~cm}$.

The infiltration solutions were prepared by dissolving the respective metal nitrates in water along with a surfactant. Metal concentration in the solution was kept to $1 \mathrm{M}$. Prior to infiltration, the symmetrical STN94/YSZ cells were weighed and the infiltration was then performed using the following infiltration procedure: A drop of infiltrate solution was placed upon the surface of the cell where the capillary forces are expected to ensure an equal distribution through the porous structure down to the electrode-electrolyte interface. The drop was left on the surface for one minute, and then dried off using an absorbent laboratory tissue. Both sides of the symmetric cell 
were subjected to this procedure before the cell was heated to $350^{\circ} \mathrm{C}$ for 30 minutes. After heat treatment the cells were wiped off, using a laboratory tissue, to remove residues from the surface, and then infiltrated again. This infiltration procedure was repeated three times in total, with the last heat-treatment step at $350^{\circ} \mathrm{C}$ prolonged to two hours. After the prolonged heat-treatment, the infiltrated cells were weighed again in order to determine the catalyst load. Emphasis should be made on the handling of the cells after being infiltrated since nanoparticles were now present inside the electrode backbone. These nanoparticles were attached to the surface, but even so, the cells had to be handled following safety guidance for handling of nanoparticles.

\subsection{Microstructural Characterization}

The microstructure of the cells was investigated from a fractured cross-section, without any pretreatment of the samples, using scanning electron microscopy (SEM) (ZEISS Merlin, Carl Zeiss, Germany). The microstructure of the samples was investigated directly a) after infiltration, b) after being heated to $850^{\circ} \mathrm{C}$ and reduced for 24 hours in humidified hydrogen, and c) after the whole test protocol had been performed. In order to analyze the catalyst distribution through the electrodes, all of them were investigated on five to seven different points between the electrode surface and the electrode-electrolyte interface,

\subsection{Electrochemical characterization}

Prior to the electrochemical characterization, the infiltrated cells were hand-painted with a Pt-paste current collection layer. Following this, the cells were mounted in an experimental setup allowing for simultaneous testing of four symmetrical cells per test. A detailed description of the setup can be found elsewhere [20]. All tested samples were exposed to the test protocol described below, and 4-5 cells were tested for each type of catalyst infiltration. 
The test protocol performed on each cell in this work is schematically represented in figure 1 and included the following steps: Heating up to $850^{\circ} \mathrm{C}$ in air followed by a 30 minutes reduction of the cells in $4 \% \mathrm{H}_{2} \mathrm{O} / \mathrm{H}_{2}$. After the cells had been reduced a first reference EIS measurement was performed at the reference conditions; $4 \% \mathrm{H}_{2} \mathrm{O} / \mathrm{H}_{2}$ at $850^{\circ} \mathrm{C}$, marked with $\# 1$ in figure 1, followed by impedance measurements at every $50^{\circ} \mathrm{C}$ down to $450^{\circ} \mathrm{C}$ in $4 \% \mathrm{H}_{2} \mathrm{O} / \mathrm{H}_{2}$. Afterwards the temperature was raised back to $850^{\circ} \mathrm{C}$ for reference measurement $\# 2$. Then the steam content was increased to $50 \%$ and EIS measurements were performed at every $50^{\circ} \mathrm{C}$ from $850^{\circ} \mathrm{C}$ down to $650^{\circ} \mathrm{C}$. Afterwards the temperature was raised again and the reference measurement $\# 3$ was performed. The $4 \% \mathrm{H}_{2} \mathrm{O} / \mathrm{H}_{2}$ atmosphere was then changed to $50 \% \mathrm{CO}_{2} / \mathrm{CO}$ and EIS measurements were performed at every $50^{\circ} \mathrm{C}$ down to $650^{\circ} \mathrm{C}$ followed by reference measurement $\# 4$ at $850^{\circ} \mathrm{C}$. Following the reference measurement, a short 48 hours stability test at $650^{\circ} \mathrm{C}$ in $50 \% \mathrm{CO}_{2} / \mathrm{CO}$ was performed, to investigate the tolerance of the electrodes to carbon containing fuels. Finally, after the short stability test, the final reference measurement $\# 5$ was performed before cooling down to room temperature in air.

[Figure 1 about here]

The electrochemical impedance spectroscopy was performed at OCV using a Gamry Reference 600 potentiostat. Impedance spectra were recorded between $0.01 \mathrm{~Hz}-1 \mathrm{MHz}$ with 10 points/decade applying a $50 \mathrm{mV}$ amplitude.

Analysis of the impedance data was performed using impedance transforms in the Python-based software RAVDAV developed at DTU Energy [19]. The series resistances $\left(\mathrm{R}_{\mathrm{s}}\right)$ observed in the impedance data were not corrected for ohmic contributions arising from the Pt leads in the 
experimental setup, as the lead resistance based on previous experiments is estimated to be less than $5 \%$ of the measured $R_{s}$.

\section{Results and Discussion}

\subsection{Electrode microstructure and electrocatalyst load}

Figure 2 shows the microstructure of the different infiltrated cells right after the infiltration procedure had been performed. The different metal infiltrations resulted in different types of nanostructures of sizes 5-10 $\mathrm{nm}$. It was found that the infiltration procedure had resulted in a uniform distribution of the infiltrate throughout the electrode, since no variations in the catalyst distribution were found between the five to seven different points investigated on each electrode. The cobalt and iron infiltrated cells had spherical nanostructures (figure $2 \mathrm{a}$ and $\mathrm{b}$ ), while the nickel infiltrated samples showed a nano-needle structure (figure 2c).

[Figure 2 about here]

The average weight gain per square centimeter of each type of electrode after finishing the infiltration procedure can be seen in table 1 . The increase in mass indicates the amount of metal catalyst introduced into the STN backbone. Notably, the weight gain of the nickel- and iron-oxide infiltrated are almost identical while the cobalt-oxide infiltrated samples is smaller.

[Table 1 about here]

The final morphology of the infiltrated cells after the entire test protocol can be seen in figure 3 . It can here be observed that independent of the initial morphology, the final morphology of the nanostructures is the same, namely spherical nanostructures with a diameter of 100-200 nm. This evidences that the particles have agglomerated into larger particles due to the high temperatures. 
In addition, it was found from the SEM investigation that this morphology is already obtained after 25 hours at $850^{\circ} \mathrm{C}$. The observed growth of the nanoparticles, which has also been reported elsewhere in the literature [14], ultimately reduces the triple phase boundary and the amount of the active reaction sites, which in return will decrease the performance for these cells.

[Figure 3 about here]

\subsection{Electrochemical characterization}

\subsubsection{Impedance analysis}

The characteristic impedance spectra of $\mathrm{Co}, \mathrm{Fe}$, and $\mathrm{Ni}$ infiltrated $\mathrm{STN}$ backbones at $850^{\circ} \mathrm{C}$ in $4 \%$ $\mathrm{H}_{2} \mathrm{O} / \mathrm{H}_{2}$ are shown in figure 4 . A single arc with a characteristic frequency between 15 and $35 \mathrm{~Hz}$ can be observed in the impedance spectra. Additionally, a small ohmic contribution to the impedance can be observed at the low frequencies. This latter contribution is suspected to be a result of a non-stationary system, which could be caused by a small degree of nanoparticle agglomeration. As a consequence of this drift, the fit was limited to $0.1 \mathrm{~Hz}$. Constant phase elements in combination with resistances are used for the fitting of the impedance spectra, a physical interpretation of the individual impedance contributions is not within the scope of the current work. The equivalent circuit used for the fitting of impedance spectra was $L-R-R_{1} Q_{1}-R_{2} Q_{2}$ (where $\mathrm{Q}$ is a constant phase element, $\mathrm{R}$ is the resistance and $\mathrm{L}$ is the inductance). Notably, the equivalent circuit contains two constant phase elements, which is necessary in order to obtain a decent fit. The high frequency constant phase element used in the fitting, makes up less than $4 \%$ of the total polarization resistance, meaning that the other arc completely dominates the impedance spectra. The equivalent circuit model was used for parameterization of the spectra to derive the ohmic and polarization resistance $R_{p}$ as the sum of $R_{1}$ and $R_{2}\left(R_{1}+R_{2}\right)$, without any further analysis 
of the underlying reaction mechanism. Examples of this fitting are also shown in figure 4. Notably, the polarization resistance, $R_{p}$, is the resistance arising from the voltage loss related to the faradaic current in the electrode.

[Figure 4 about here]

\subsubsection{Reproducibility of electrode performance}

The reproducibility of the electrode performance of nominally identically prepared electrodes is shown in figure 5 for nickel infiltrated STN electrodes in the temperature range from 650 to $850^{\circ} \mathrm{C}$. The polarization resistance $R_{p}$ of all cells shows an Arrhenius behavior with similar slopes, indicating an identical activation energy. The parallel shift observed in figure 5 indicates that the differences observed in the polarization resistance is a consequence of the differences in the microstructure of the electrode, in accordance with the pre-exponential factor of the Arrhenius equation, which will be described in detail in section 3.2.4. Notably, the cell with the lowest preexponential factor (i.e. the lowest interception in the Arrhenius plot), is the cell with the highest Ni load (Ni\#2: $0.72 \mathrm{mg} \cdot \mathrm{cm}^{-2}$ ), and the cell with the second highest pre-exponential factor, is the cell with the lowest $\mathrm{Ni}$ load $\left(\mathrm{Ni} \# 3: 0.54 \mathrm{mg} \cdot \mathrm{cm}^{-2}\right)$, see table 2 . An explanation for this could be found in the agglomeration of the nanoparticles, since a higher loading could lead to larger agglomerates, which results in less independent nanoparticles and lower TPB. On the contrary, lower loading, would lead to less agglomeration and thus a higher degree of independent nanoparticles. In conclusion, the parallel shift observed in figure 5 is considered a consequence of differences in the infiltrate structure caused by difference in infiltrate load, however, differences in the electrode backbone cannot be excluded.

[Figure 5 about here] 
[Table 2 about here]

\subsubsection{Influence of gas atmosphere on electrode performance and stability}

Figure 6 gives an overview of the electrode materials performance and degradation throughout the experiment, as determined from the reference measurements. The polarization resistance of the pure STN backbone increased after being exposed to high $\mathrm{pO}_{2}$, which is also observed for the cobalt and nickel infiltrated samples. In contrast, the iron infiltrated cells show a decrease in polarization resistance after being exposed to high $\mathrm{pO}_{2}$ containing atmospheres. The increase in the polarization resistance of the STN backbone can be related to the defect chemistry decreasing the electronic conductivity with higher $\mathrm{pO}_{2}$. Moreover, it can in figure 6 be observed that infiltrating the electrode backbone, with either cobalt, nickel or iron, gives rise to a much lower polarization resistance, when compared to pure STN. This shows the good electrocatalytic properties of these three metals. However, their stability seems to be affected by the oxygen partial pressure, which has to be taken into account when analyzing the electrode performance in various atmospheres.

[Figure 6 about here]

As stated earlier, several cells of each infiltration have been tested in this work, and all the reported values have been averaged over 4-5 cells. The average polarization resistance as a function of atmospheres is shown in figure 7 for the cobalt, nickel, and iron infiltrations.

[Figure 7 about here] 
From figure 7 it can be seen that the cobalt and nickel infiltrated cells obtain a lower polarization resistance in both $50 \% \mathrm{H}_{2} \mathrm{O} / \mathrm{H}_{2}$ and in $50 \% \mathrm{CO}_{2} / \mathrm{CO}$ when compared to the $4 \% \mathrm{H}_{2} \mathrm{O} / \mathrm{H}_{2}$. However, from the reference measurements in figure 6 , it was also clear that the initial performance in $4 \%$ $\mathrm{H}_{2} \mathrm{O} / \mathrm{H}_{2}$ was never obtained again, suggesting irreversible changes of the electrode. A decrease in polarization resistance has been observed for the $\mathrm{Ni}$-cermet electrodes as well and has been ascribed to the OCV conditions. When the cell is held at OCV the polarization resistance will be determined by the hydrogen evolution reaction and the hydrogen oxidation reaction. When increasing the steam content, the concentration of reactants for the hydrogen evolution reaction is increased and the overall polarization resistance decreases. On the contrary, it can be seen that in the humidified hydrogen atmosphere, containing 4\% steam, the iron infiltrated cells have the lowest polarization resistance, which is in good agreement with previous results using single-phase iron fuel electrodes for SOCs [21]. However, the polarization resistance of the iron infiltrated cells rises dramatically in both $50 \% \mathrm{H}_{2} \mathrm{O} / \mathrm{H}_{2}$ and even further in $50 \% \mathrm{CO}_{2} / \mathrm{CO}$ and iron becomes the worst performing electrocatalyst of the three metals (figure 7). However, it can be seen in figure 6 that the reference polarization resistance for the iron infiltrated cells is decreasing with time. This suggests that any changes observed in the polarization resistance in figure 7 are related to changes in the gas atmosphere, since the overall instability of the cells can be regarded as minor changes, when compared to the changes observed in figure 7. Overall, figure 6 and figure 7 suggests that the iron catalyst interacts differently with the gas atmospheres, than the nickel and cobalt, which will be investigated further using the model presented in section 3.2.4.

\subsubsection{Temperature dependence}

Understanding the interactions between the gas atmosphere and the individual catalysts is important for further optimization of the electrode performance. Hence, in order to obtain a deeper 
understanding of the kinetics in the electrochemical reactions, one approach is to look at the temperature dependence of the polarization resistances, as can be seen in figure 8 for the cobalt, iron and nickel infiltrations. The polarization resistance of all the infiltrated cells shows an Arrhenius behavior, from which the activation energy $\mathrm{E}_{\mathrm{a}}$ and the pre-exponential factor, $\mathrm{A}$, can be derived (equation 1).

$$
\ln \left(\mathrm{R}_{\mathrm{p}}\right)=\ln (\mathrm{A})-\frac{\mathrm{E}_{\mathrm{a}}}{\mathrm{RT}}
$$

[Figure 8 about here]

The averaged activation energy for the different infiltrations in the different atmospheres can be seen in table 3. When the atmosphere is changed from $4 \% \mathrm{H}_{2} \mathrm{O} / \mathrm{H}_{2}$ to $50 \% \mathrm{H}_{2} \mathrm{O} / \mathrm{H}_{2}$, the corresponding increase in $\mathrm{pO}_{2}$ is accompanied by an increase in the activation energy. This increase in activation energy could be related to oxidation of the metal catalyst, for which reason the chemical stability of the metal towards oxidation was estimated from Ellingham diagrams [22]. The maximum $\mathrm{pO}_{2}$ tolerance of the metals found from the Ellingham diagrams are stated in table 4 together with the $\mathrm{pO}_{2}$ present in the three tested atmospheres.

\section{[Table 3 about here]}

From table 4 it is clear that the nickel and cobalt nanoparticles are stable as metals at all test conditions. In contrast, the oxygen partial pressure in both $50 \% \mathrm{H}_{2} \mathrm{O} / \mathrm{H}_{2}$ and $50 \% \mathrm{CO}_{2} / \mathrm{CO}$ is close to the maximum tolerance of the iron nanoparticles. Hence, a partial or even full re-oxidation of 
the iron nanoparticles is likely in both $50 \% \mathrm{H}_{2} \mathrm{O} / \mathrm{H}_{2}$ and $50 \% \mathrm{CO}_{2} / \mathrm{CO}$, which could also be reflected in a stronger interaction between iron and oxygen.

\section{[Table 4 about here]}

Because of the absence of information, a comparison with literature values for the activation energy of the transition metal nanoparticles is not possible. However, the activation energies for SoA Ni-YSZ SOC fuel electrodes could be found ranging from $1.01 \mathrm{eV}$ and up to $1.47 \mathrm{eV}$ for the hydrogen-water reaction, depending on the fabrication method, steam content and test conditions [23-24, 26-28]. In table 3 one can observe similarities between the change in activation energy with atmosphere, between the nickel cermet and the nickel infiltrated samples. This correlation indicates that even though the nickel has been infiltrated as nanoparticles, the activation energy is not affected significantly by the Ni morphology, indicating that the reaction mechanism is not affected by the morphology of the catalyst. Moreover, it can be observed in table 3 that when the steam content is increased from $4 \%$ to $50 \%$, the activation energy of the cobalt, nickel, and iron infiltrated cells increases by approximately $50 \%, 14 \%$, and $25 \%$, respectively. But, when the atmosphere is changed from $50 \% \mathrm{H}_{2} \mathrm{O} / \mathrm{H}_{2}$ to $50 \% \mathrm{CO}_{2} / \mathrm{CO}$ the activation energy of cobalt and iron infiltrated cells decreases by $13 \%$ and $17 \%$, respectively, while the activation energy of the nickel infiltrated cells increases even further by $11 \%$. This indicates that the changes in the reaction mechanisms following changes in the different atmospheres, are diverse and a deeper analysis is therefore necessary. This can be done by analyzing the activation energy and the pre-exponential factor of the Arrhenius equation in more detail.

In order to complement the above observations the pre-exponential factor, A, in each atmosphere for the different infiltrations was calculated and presented in table 3. An analysis of the pre- 
exponential factor can give further knowledge of the kinetics of the reaction, since the preexponential factor describes, amongst others, the kinetics of the electrochemical reaction [29]. The pre-exponential factor, $\mathrm{A}$, in the Arrhenius equation is a combination of a precursor equilibrium constant, $\mathrm{K}_{\mathrm{P}, \mathrm{O}}$, representing the ratio of the reactant concentration in the reactive position, a transmission coefficient, $\kappa_{\mathrm{el}}$, related to the probability of the reaction, and a frequency factor, $v_{\mathrm{n}}$, which represents the frequency of attempts on the energy barrier $E_{a}$. The pre-exponential factor, A, can, therefore, be described as [30]:

$$
\mathrm{A}=\mathrm{K}_{\mathrm{P}, \mathrm{O}} \cdot \kappa_{\mathrm{el}} \cdot v_{\mathrm{n}}
$$

The approach followed in this work is to develop a model that allows for analyzing the kinetics of the electrochemical reaction by correlating the activation energy with the pre-exponential factor. The model used for the analysis is described further in the following section.

\subsubsection{Model description}

In order to better understand the electrode processes, a theoretical model was deduced based on four assumptions and the harmonic oscillator, for which the restoring force is described by Hookes law (equation 3).

$$
\mathrm{F}=\mathrm{k} \cdot \mathrm{x}
$$

Where $\mathrm{F}$ is the force, $\mathrm{k}$ is the force constant and $\mathrm{x}$ is the bond length. The harmonic oscillator is applied to describe the bond between the adsorbed reactant and the metal-catalyst, an approach which has been confirmed to be valid at low overpotentials up to $0.2 \mathrm{~V}$ [31]. In the following, the four assumptions used in deducing the model are described in more detail. 
Firstly, it is assumed that the electrode potential for a given atmosphere is identical for the individual cells and not influenced by the electrocatalyst at OCV conditions. This follows from the electrode potential being determined by the activity of the oxygen ions in the electrolyte and the oxygen in the atmosphere, which is independent of the electrocatalyst [32].

Secondly, it is assumed that the force term in the harmonic oscillator is proportional to the binding energy of the adsorbed species and that this binding energy is directly proportional to the activation energy of the transition state (equation 4) [33]. This assumption is reasonable, since the energy needed to overcome the activation barrier, the activation energy, must be translated into another form of energy, namely binding energy between the absorbent and the catalytic site. Furthermore the attractive force which the adsorbed molecule feels towards the catalytic site must also be proportional to the energy stored in that bond, if the bond length is fixed.

$$
\mathrm{F} \propto \mathrm{E}_{\text {binding }} \propto \mathrm{E}_{\mathrm{a}}
$$

Hence, higher activation energy would give rise to an increase in the force, F, which would result in a change in either the bond length $\mathrm{x}$ or the force constant $\mathrm{k}$ in accordance to Hooke's law.

Thirdly, it is assumed that the bond length, $x$, between the adsorbent and the metal is fixed. This is reasonable since it is a chemical adsorption process and the adsorbent and the metal surface are as close together as they can be. The model is thus analyzing the intermediate regime between the adsorption and the electrocatalytic reaction. A change in activation energy can therefore only give rise to a change in the force constant, $\mathrm{k}$ [34]. This force constant can be expressed as a function of the period of the harmonic motion and the mass of the adsorbed reactant, (equation 5). 
Error!

$$
\mathrm{k}=\frac{4 \pi^{2} \cdot \mathrm{m}}{\mathrm{T}^{2}} \stackrel{\mathrm{f}=\frac{1}{\mathrm{~T}}}{\Longrightarrow} \mathrm{k}=4 \pi^{2} \cdot \mathrm{m} \cdot \mathrm{f}^{2}
$$

Bookmark

not

defined.(5)

Where $\mathrm{k}$ is the force-constant, $\mathrm{T}$ is the period, $\mathrm{m}$ is the mass of the adsorbed reactant and $\mathrm{f}$ is the oscillating frequency. Notably, in equation 5 it can be seen that a change in the mass will result in a one to one increase in the force-constant, while an increase in the oscillating frequency will result in a power-law increase of the force-constant [34].

In order to correlate equation 5, with the pre-exponential factor from the Arrhenius equation (equation 1) a new variable, $\varphi$, must be introduced instead of the mass term in equation 5 . The variable $\varphi$ is proportionally dependent on the precursor equilibrium constant, $K_{P, 0}$, and hence describes the nature of the reactant and reaction sites. Furthermore, since the harmonic oscillation is happening in the region between the molecule getting adsorbed and the reaction taking place, it is reasonable to imagine that an increase in the oscillation frequency would result in an increase in the attempts on reaction, namely the frequency factor of the pre-exponential factor. The oscillating frequency can therefore be replaced by the turnover frequency, which is proportional to the frequency factor of the pre-exponential factor: $\mathrm{f}_{\text {turnover }} \equiv \kappa_{\mathrm{el}} \cdot v_{\mathrm{n}}$, where $\kappa_{\mathrm{el}}$ is the transmission coefficient and $v_{\mathrm{n}}$ is the frequency factor.

$$
\mathrm{k} \propto 4 \pi^{2} \cdot \varphi \cdot \mathrm{f}_{\text {turnover }}^{2}
$$

Error!

Bookmark 
The fourth and final assumption of the model is that there is a linear correlation between the preexponential factor and the force-constant of the harmonic oscillator (equation 7). This assumption is reasonable since the pre-exponential factor and the force-constant both describes the kinetics of the electrochemical reaction and the harmonic motion, respectively. The model utilizes the parallel between an adsorption bond and the harmonic oscillator to describe the kinetics of a reaction involving adsorption to the catalyst surface. A linear correlation between the force-constant of the harmonic oscillator and the pre-exponential factor is hence reasonable for the purpose of the model.

Error!

$$
\ln (\mathrm{A})=\mathrm{c}_{1} \cdot \mathrm{k}+\mathrm{c}_{2}
$$

\section{Bookmark}

not

defined.(7)

Where $c_{1}$ and $c_{2}$ are constants.

Combining the four assumptions yields equation 8 , which describes the pre-exponential factor as a function of two constants, a variable, $\varphi$, which is proportionally dependent on the precursor equilibrium constant and finally a frequency term, which is dependent on the transmission coefficient and the frequency factor.

$$
\ln (A) \propto 4 \pi^{2} \cdot c_{1} \cdot \varphi \cdot f_{\text {turnover }}^{2}+c_{2}
$$


In total, according to equation 8 , equation 3 , equation 4 , and by combining all constant terms into one constant, that is absorbed into proportionality, a general expression for the model can be obtained (equation 9).

Error!

$$
\mathrm{E}_{\mathrm{a}} \propto\left(4 \pi^{2} \cdot \mathrm{c}_{1} \cdot \varphi \cdot \mathrm{f}_{\text {turnover }}^{2}+c_{2}\right) \cdot x
$$

\section{Bookmark}

\section{not}

defined.(9)

According to equation 9, if the change in the natural logarithm of the pre-exponential factor diverges from the change in the activation energy, it can only be due to a change in the frequency term, since this is to the power of two. While if the change in the natural logarithm of the preexponential factor does not diverge from the change in the activation energy, it can only be a result of changes in the linear term, $\varphi$. Therefore, a power law correlation between the percentage change in $\Delta_{\%} \ln (\mathrm{A})$ and $\Delta_{\%} \mathrm{E}_{\mathrm{a}}$, is a direct result of a change in the turnover frequency, $\mathrm{f}_{\text {turnover. }}$ On the other hand, if a one to one correlation is observed between the percentage change in $\Delta_{\%} \ln (\mathrm{A})$ and $\Delta_{\%} \mathrm{E}_{\mathrm{a}}$, it indicates a change in $\varphi$ which can be correlated to a change the precursor equilibrium constant. Notably, due to the standard deviations observed in table 3, and due to a small divergence between a linear and power-law expression at smaller values, the correlation is defined to be power-law correlated if and only if $\left|\Delta_{\%} \ln (\mathrm{A})\right|-\left|\Delta_{\%} \mathrm{E}_{\mathrm{A}}\right|>6 \%$ else, it is considered as a one to one correlation. Notably, a change in the turnover frequency does not exclude a minor change in the nature of the reaction. 
In short, a one to one correlation between the change in activation energy and the change in the pre-exponential factor indicates a change in the adsorbed molecules or the number of active reaction sites. On the other hand, a power law correlation indicates a change in the frequency of attempts on the energy barrier in the electrochemical reaction, and thus the turnover frequency. For the purpose of analyzing the results with this model, the percentage change in the logarithm of the pre-exponential factor and the percentage change in the activation energy was calculated (table 5). The difference between these two values was also calculated and is also presented in table 5 .

\section{[Table 5 about here]}

An increase in activation energy is followed by an increase in the pre-exponential factor for the nickel and the cobalt infiltrations, when the atmosphere is changed from $4 \% \mathrm{H}_{2} \mathrm{O} / \mathrm{H}_{2}$ to $50 \%$ $\mathrm{H}_{2} \mathrm{O} / \mathrm{H}_{2}$ (table 5). Furthermore, the change in the pre-exponential factor exceeds the change in activation energy. The iron infiltrations also experience an increase in both activation energy and in the pre-exponential factor when the steam content is increased, however, the increase in activation energy exceeds the change in the pre-exponential factor. Also, when the atmosphere is changed from $50 \% \mathrm{H}_{2} \mathrm{O} / \mathrm{H}_{2}$ to $50 \% \mathrm{CO}_{2} / \mathrm{CO}$ the activation energy and the pre-exponential factor for the nickel infiltrated cells increases by a similar amount. Meanwhile, the cobalt and iron infiltrated cells both experience a decrease in activation energy and pre-exponential factor of a similar size. In short, the differences observed between the different infiltrated cells suggest differences in the underlying electrode processes.

The correlations observed between the change in activation energy and the change in the logarithm of the pre-exponential factor are furthermore summarized in table 5. It can here be seen that the 
cobalt and nickel infiltrated samples behave similarly in regard to the correlation, namely that they both experiences a power law increase when the steam content is raised from $4 \%$ to $50 \%$ indicating a higher turnover frequency. Notable, this does not exclude a minor change in the reactant concentration, reactive position, and transmission coefficient, since a minor one to one increase would be overshadowed by the power law increase. However, when the atmosphere is changed from $50 \% \mathrm{H}_{2} \mathrm{O} / \mathrm{H}_{2}$ to $50 \% \mathrm{CO}_{2} / \mathrm{CO}$ both the nickel and cobalt infiltrated cells experience a one to one correlation, indicating a change in the nature of the adsorbent, the nature of the adsorption bond, or a change in the amount of active reaction sites, which is logical. However, the iron infiltrated cells behave differently than the other two infiltrations since they experience an inverse power-law correlation when the steam content is increased to $50 \%$. This is quite interesting and indicates several things, which will be discussed shortly. Furthermore, when the atmosphere is changed to $50 \% \mathrm{CO}_{2} / \mathrm{CO}$ the iron infiltrated cells experience a negative power-law correlation that indicates a decrease in the turnover frequency.

The inverse power-law correlation observed for the iron infiltrated cells when the steam content is increased to $50 \%$ suggests several things. Firstly, the increase in the activation energy describes an increase in the binding energy of the transition state. Secondly, the inverse power-law correlation indicates, amongst others, a change in the turnover frequency, but due to the inverse correlation, it is not a simple decrease in the turnover frequency, but rather a decrease in the turnover frequency combined with an increase in the reactant concentration in the reactive position. A combination of these two points suggests that the adsorbed reactant in the reaction is changed, meanwhile, the turnover frequency for the adsorption process is decreased. Thus, once adsorbed to the surface, the reactant does not desorb again. However, this blockade does not simply reduce the amount of catalytic sites, but rather changes the reaction mechanism. After the blockade 
of catalytic sites, the reaction will take place, but now through the adsorbed specie. In short, the model suggests that the iron nanoparticles experience partial surface blockade in the $50 \% \mathrm{H}_{2} \mathrm{O} / \mathrm{H}_{2}$ atmosphere, which is also in good agreement with the oxygen partial pressures given in table 4. There exist three possibilities for the blockade of the catalytic sites, which are schematically presented in figure 9. All three start with the formation of the adsorption bond between the water molecule and the catalytic site on the iron nanoparticle. Thereafter, there are three possible reaction mechanisms. (I): One hydrogen atom is dissociated from the water molecule and the now $\mathrm{OH}$ adsorption bond is too strong to be broken and the reaction must go through the OH-bond. (II): The water molecule remains adsorbed with an adsorption bond too strong to be broken, and the reaction must go through the water molecule. (III): The water molecule dissociates both hydrogen atoms, and the oxygen remains firmly adsorbed, resulting in an oxygen blockade of the nanoparticles. Ultimately, all three reaction mechanisms result in a blockade of the catalytic sites and the reactions now need to go through these adsorbed species. The correct reaction mechanism could be identified by near ambient pressure X-ray photon spectroscopy (NAP-XPS) which can distinguish between the adsorbed species [35].

[Figure 9 about here]

\section{Conclusion}

In this work, the electrocatalytic activity of three transition metals, namely nickel, cobalt and iron has been investigated as catalysts for fuel electrodes in solid oxide cells. Infiltration of the metals as nanoparticles into a porous STN backbone was found to be a viable route to compare the electrocatalytic activity of the electrocatalysts. The Ni and Co infiltrated electrodes showed similar performance in carbon containing atmospheres, indicating a good carbon tolerance of these 
electrode materials. In $50 \% \mathrm{H}_{2} \mathrm{O} / \mathrm{H}_{2}$ at $850^{\circ} \mathrm{C}$, polarization resistances of 0.51 and $0.52 \Omega \mathrm{cm}^{2}$ were observed for the nickel and cobalt infiltrated cells, respectively, while significantly higher polarization resistances of the iron infiltrated cells indicated a problem with iron at high oxygen partial pressures. In order to gain further insight into the interplay between the gas composition and electrochemical reaction mechanism, a model was derived based on the harmonic oscillator. The model allows for the correlation of changes in the atmosphere with changes in the turnover frequency or changes in the nature of the electrochemical reactants. To the authors' knowledge, a model like this has not previously been presented in literature. By using the model, it was determined that increasing the steam content from $4 \% \mathrm{H}_{2} \mathrm{O} / \mathrm{H}_{2}$ to $50 \% \mathrm{H}_{2} \mathrm{O} / \mathrm{H}_{2}$ on the iron infiltrated electrode introduces a surface blockade of the catalytic sites, which forces the reaction mechanism to change. On the contrary, the same increase in steam content enhances the turnover frequency on both the cobalt and nickel infiltrated electrodes, without changing the reaction mechanism. The model derived in this work is not restricted to a specific cell design, but can be applied to any temperature dependent electrochemical system, where molecules are adsorbed to the surface of the electrocatalyst.

\section{Acknowledgment}

The authors would like to acknowledge the colleagues at DTU Energy for technical assistance and fruitful discussions. Furthermore, the authors would like to acknowledge the financial support from the project "BALANCE" (European Union's Horizon 2020 research and innovation program under grant agreement number 731224). 


\section{References}

[1] A. Boudghene Stamboli, E. Traversa. Solid oxide fuel cells (SOFCs): a review of an enviromentally clean and efficient source of energy. Renewable and Sustainable Energy reviews. 2002,6 .

[7] L.V. Saraf, D. R. Baer, A. S. Lea, Z. H. Zhu, J. J. Strohm, S. D. Sitzman, and D. L. King. Bulk Migration of Ni/NiO in Ni-YSZ during Reducing Conditions. Journal of The Electrochemical Society. 2010, Vol. 157, 4.

[2] Niakolas, Dimitros K. Sulfur poisoning of Ni-based anodes for Solid Oxide Fuel Cells in H/Cbased fuels. Applied Catalysis A: General. 2014, 486.

[3] Meng Li, Bin Hua, Jing-Li Luo, San Ping Jiang, Jian Pu, Bo Chi an Li Jian. Carbon-tolerant Ni-based Cermet anodes modified by proton conducting yttrium- an ytterbium- doped barium cerated for direct methane solid oxide fuel cells. Journal of Materials Chemistry A. 2015, 3.

[4] Shanwen Tao, and John T. S. Irvine. Discovery and characterization of novel oxide anodes for solid oxide fuel cells. the Chemical Record. 2004, Vol. 8.

[5] K. Haga, S. Adachi, Y. Shiratori, K. Itoh, K. Sasaki. Poisoning of SOFC anodes by various fuel impurities. Solid State Ionics. 2008, 179.

[6] John Kirtley, Anand Singh, David Halat, Thomas Oswell, Josephine M. Hill, and Robert A. Walker. In Situ Raman Studies of Carbon Removal from High Temperature Ni-YSZ Cermet Anodes by Gas Phase Reforming Agents. J. Phys. Chem. C. 2013, Vol. 117, 49.

[8] A. Mohammed Hussain, Jens V.T. Høgh, Wei Zhang, and Nikolaos Bonanos. Efficient ceramic anodes infiltrated with binary and ternary electrocatalysts for SOFCs operating at low temperatures. Journal of Power Sources. 2012, 216.

[9] T. Ramos, C. Bernuy-Lopez, B. R. Sudireddy, J. J. Bentzen, W. Zhang, P. S. Jørgensen, L. T. Kuhn. Performance-Microstructure Relations in Ni/CGO Infiltrated Nb-doped SrTiO3 SOFC Anodes. ECS Transactions. 2012, 45 (1).

[10] Peter Blennow, Kent K. Hansen, L. Reine Wallenberg, Mogens Mogensen. Electrochemical characterization and redox behavior of Nb-doped SrTIO3. Solid State Ionics. 2009, 180.

[11] Maarten C. Verbraeken, Boris Iwanschitz, Andreas Mai, and John T. S. Irvine. Evaluation of $\mathrm{Ca}$ Doped La0.2Sr0.7TiO3 as an Alternative Material for Use in SOFC Anodes. Journal of The Electrochemical Society,. 2012, 159(11).

[12] Qianli Ma, Frank Tietz, André Leonide, Ellen Ivers-Tiffée. Electrochemical performances of solid oxide fuel cells based on Y-substituted $\mathrm{SrTiO} 3$ ceramic anode materials. Journal of Power Sources. 2011, 196.

[13] M. C. Verbraeken, T. Ramos, K. Agersted, Q. Ma, C. D. Savaniu, B. R. Sudireddy, J. T. S. Irvine, P. Holtappels, and F. Tietz. Modified strontium titanates: from defect chemistry to SOFC anodes. RSC Advances. 2015, 5(2). 
[14] Zhangbo Liu, Beibei Liu, Dong Ding, Mingfei Liu, Fanglin Chen and Changrong Xia. Fabrication and modification of solid oxide fuel cell anodes via wet impregnation/ infiltration technique. Journal of Power Sources. 2013, 237.

[15] T. Ramos, S. Veltzé, B. R. Sudireddy, P. S. Jørgensen, L. Theil Kuhn, P. Holtappels. Effect of $\mathrm{Ru} / \mathrm{CGO}$ versus Ni/CGO Co-Infiltration on the Performance and Stability of STN-Based SOFCs. Fuel Cells 14. 2014, 6.

[16] Andre L.M. da Silva, Johan P. den Breejen, Lisiana V. Mattos, Johannes H. Bitter, Krijn P. de Jong, and Fábio B. Noronha. Cobalt particle size effects on catalytic performance for ethanol steam reforming - Smaller is better. Journal of Catalysis. 2014, Vol. 318.

[17] Martin Anderson, Hedvig Paradis, Jinliang Yuan, and Bengt Sundén. Review of Catalyst Materials and Catalytic Steam Reforming Reactions in SOFC Anodes. International Journal of Energy Research. 2011, Vol. 35.

[18] T. Setoguchi, K. Okamoto, K. Eguchi, and H. Arai. Effects of Anode Material and Fuel on Anodic Reaction of Solid Oxide Fuel Cells. Journal of The Electrochemical Society. 1992 Vol. 139 no. 10

[19] Graves, Chris. RAVDAV data analysis software, version 0.9.8. DTU. 2015.

[20] J. Karczewski, B. Riegel, M. Gazda, P. Jasinski, and B. Kusz. Electrical and structural properties of Nb-doped SrTiO3 ceramics. J Electroceram. 2010, Vol. 24.

[21] E. Baur, H. Preis. Uber die Eisenoxyd-Kathode in der Kohle-Luft-Kette. Z. Elektrochem. 1937, 43.

[22] M.V. Glazoff, S.C. Marschman and N. Solberg. On a Thermodynamic Approach to Material Selection for Service in Aggressive Multi-Component Gaseous and/or Vapor Environments. Idaho Falls : Idaho National Laboratory, 2015.

[23] M. Brown, S. Primdahl, and M. Mogensen. Structure/Performance Relations for Ni/YttriaStabilized Zirconia Anodes for Solid Oxide Fuel Cells. Journal of The Electrochemical Society. 2000, Vol. 147, 2.

[24] Weiping Pan, Kongfa Chen, Ni Ai, Zhe Lü, and San Ping Jiang. Mechanism and Kinetics of Ni-Y2O3-ZrO2 Hydrogen Electrode for Water Electrolysis Reactions in Solid Oxide Electrolysis Cells. Journal of The Electrochemical Society. 2016, Vol. 163, 2.

[25] V. Yurkiv, D. Starukhin, H.-R. Volpp, and W. G. Bessler. Elementary Reaction Kinetics of the $\mathrm{CO} / \mathrm{CO} 2 / \mathrm{Ni} / Y S Z$ Electrode. Journal of The Electrochemical Society,. 2011, Vol. 158, 1.

[26] P. Holtappels, L. G. J. de Haart and U. Stimming. Reaction of Hydrogen/Water Mixtures on Nickel-Zirconia Cermet Electrodes I. DC Polarization Characteristics. Journal of The Electrochemical Society. 1999, 146(5). 
[27] P. Holtappels, I. C. Vinke, L. G. J. de Haart, and U. Stimming. Reaction of Hydrogen/Water Mixtures on Nickel-Zirconia Cermet Electrodes II. AC Polarization Characteristics. Journal of The Electrochemical Society. 1999, 146(8).

[28] A. Mary Sukeshini, Bahman Habibzadeh, Benjamin P. Becker, Chad A. Stoltz, Bryan W. Eichhorn and Gregory S. Jacksona. Electrochemical Oxidation of $\mathrm{H} 2, \mathrm{CO}$, and $\mathrm{CO} / \mathrm{H} 2$ Mixtures on Patterned Ni Anodes on YSZ Electrolytes. Journal of The Electrochemical Society. 2006, 53(4).

[29] Jean-Claude Njodzefon, Johan Hjelm, Christopher R. Graves, and André Weber. Electrode Kinetics and Gas Conversion in Solid Oxide Cells. Roskilde, Denmark : Department of Energy Conversion and Storage, Technical University of Denmark, 2015.

[30] Allen J. Bard, Larry R. Faulkner. Electrochemical Methods - Fundementals and applications, 2nd Edition. s.l. : Wiley, 2001.

[31] John O'M. Bockris, Amulaya K. N. Reddy, and Maria E. Gamboa-Aldeco. Modern Electrochemistry 2A. s.1. : Springer US, 2000. 978-0-306-46166-8.

[32] B. A. van Hassel, B. A. Boukamp, and A. J. Burggraaf. Solid State Ionics, 1991, Vol. 48

[33] Xinyan Liu, Jianping Xiao, Hongjie Peng, Xin Hong, Karen Chan, and Jens K. Nørskov. Understanding trends in electrochemical carbon dioxide reduction rates. Nature Communications. 2017,8 .

[34] A. Douglas Davis. The Harmonic Oscillator. Classical Mechanics. s.l. : Elsevier, 1986.

[35] Viktoriia A. Saveleva, Vasiliki Papaefthimiou, Maria K. Daletou, Won H. Doh, Corinne Ulhaq-Bouillet, Morgane Diebold, Spyridon Zafeiratos, and Elena R. Savinova. Operando Near Ambient Pressure XPS (NAP-XPS) Study of the Pt Electrochemical Oxidation in H2O and H2O/O2 Ambients. J. Phys. Chem. C. 2016, Vol. 120, 29. 
Table 1: Average weight gain from the infiltration procedure for each electrode in $\mathrm{mg} \cdot \mathrm{cm}^{-2}$ and percentage relative to the entire mass of the cell.

\begin{tabular}{|l|c|c|}
\hline Infiltration & Weight gain $\left.\mathbf{( m g} \cdot \mathbf{c m}^{-2}\right)$ & Weight gain (\%) \\
\hline $\mathrm{CoO}$ & $0.54 \pm 0.08$ & 0.71 \\
\hline $\mathrm{FeO}$ & $0.69 \pm 0.08$ & 0.94 \\
\hline $\mathrm{NiO}$ & $0.68 \pm 0.06$ & 0.86 \\
\hline
\end{tabular}

Table 2: The slope of the linear fit alongside with the interception and weight gain in $\mathrm{mg} \cdot \mathrm{cm}^{-2}$, of the individual nickel infiltrated samples seen in figure 5

\begin{tabular}{|c|c|c|c|}
\hline Cell & Slope & Interception & Weight gain / $\mathrm{mg} \cdot \mathrm{cm}^{-2}$ \\
\hline $\mathrm{Ni} \# 1$ & 13.6 & -11.70 & 0.57 \\
\hline $\mathrm{Ni} \# 2$ & 13.2 & -10.66 & 0.72 \\
\hline $\mathrm{Ni} \# 3$ & 13.5 & -11.27 & 0.54 \\
\hline $\mathrm{Ni} \# 4$ & 13.2 & -11.10 & 0.61 \\
\hline $\mathrm{Ni}+5$ & 14.1 & -11.90 & 0.69 \\
\hline
\end{tabular}

Table 3: Calculated averaged activation energy in eV and the natural logarithm of the preexponential factor of the different metal infiltrations in the different atmospheres.

\begin{tabular}{|l|l|l|l|}
\hline Infiltration & \multicolumn{3}{|c|}{ Averaged activation energy $(\mathrm{eV})$} \\
\hline & $4 \% \mathrm{H}_{2} \mathrm{O} / \mathrm{H}_{2}$ & $50 \% \mathrm{H}_{2} \mathrm{O} / \mathrm{H}_{2}$ & $50 \% \mathrm{CO}_{2} / \mathrm{CO}$ \\
\hline $\mathrm{Co}$ & $0.96 \pm 0.02$ & $1.48 \pm 0.06$ & $1.29 \pm 0.05$ \\
\hline $\mathrm{Ni}$ & $1.17 \pm 0.03$ & $1.33 \pm 0.06$ & $1.48 \pm 0.02$ \\
\hline $\mathrm{Fe}$ & $1.52 \pm 0.11$ & $1.89 \pm 0.05$ & $1.57 \pm 0.05$ \\
\hline Pure STN94 & $1.06 \pm 0.04$ & $1.27 \pm 0.01$ & $1.25 \pm 0.02$ \\
\hline SoA Ni cermet & $1.01-1.3[22]$ & $1.47[23]$ & $1.63-1.70[24]$ \\
\hline Infiltration & \multicolumn{3}{|l|}{ Averaged natural logarithm of the pre-exponential factor } \\
\hline & $4 \% \mathrm{H}_{2} \mathrm{O} / \mathrm{H}_{2}$ & $50 \% \mathrm{H}_{2} \mathrm{O} / \mathrm{H}_{2}$ & $50 \% \mathrm{CO}_{2} / \mathrm{CO}$ \\
\hline $\mathrm{Co}$ & $9.1 \pm 0.3$ & $16.0 \pm 0.5$ & $13.0 \pm 0.2$ \\
\hline $\mathrm{Ni}$ & $11.3 \pm 0.5$ & $14.4 \pm 0.8$ & $15.7 \pm 0.5$ \\
\hline Fe & $16.3 \pm 0.6$ & $17.7 \pm 0.7$ & $12.8 \pm 0.5$ \\
\hline Pure STN94 & $7.36 \pm 0.2$ & $10.0 \pm 0.3$ & $6.7 \pm 0.3$ \\
\hline
\end{tabular}


Table 4: The tolerance of pO2 for the different infiltrations and the estimated pO2 in the different test atmospheres.

\begin{tabular}{|c|c|c|c|c|c|}
\hline Infiltration & Temp. $\left({ }^{\circ} \mathrm{C}\right)$ & $\begin{array}{l}\text { Maximum } \\
\mathrm{pO}_{2} \text { tolerance [21] }\end{array}$ & $\begin{array}{l}\mathrm{pO}_{2} \text { for } \\
4 \% \mathrm{H}_{2} \mathrm{O} / \mathrm{H}_{2}\end{array}$ & $\begin{array}{l}\mathrm{pO}_{2} \text { for } \\
50 \% \mathrm{H}_{2} \mathrm{O} / \mathrm{H}_{2}\end{array}$ & $\begin{array}{l}\mathrm{pO}_{2} \text { for } 50 \% \\
\mathrm{CO}_{2} / \mathrm{CO}\end{array}$ \\
\hline $\mathrm{Fe}+\mathrm{O}$ & $600 / 800$ & $10^{-24} / 10^{-18}$ & \multirow{3}{*}{$10^{-27} / 10^{-22}$} & \multirow{3}{*}{$10^{-24} / 10^{-19}$} & \multirow{3}{*}{$10^{-25} / 10^{-19}$} \\
\hline $\mathrm{Ni}+\mathrm{O}$ & $600 / 800$ & $10^{-20} / 10^{-14}$ & & & \\
\hline $\mathrm{Co}+\mathrm{O}$ & $600 / 800$ & $10^{-21} / 10^{-15}$ & & & \\
\hline
\end{tabular}

Table 5: Overview of the change in the activation energy, the change in the natural logarithm of the pre-exponential factor, and the difference between these two parameters, for the different infiltrates when changing from one atmosphere to another. Furthermore, the correlation in accordance to equation 3 and 8 is also summarized here.

\begin{tabular}{|l|l|l|l|}
\hline $4 \% \mathrm{H}_{2} \mathrm{O} / \mathrm{H}_{2} \rightarrow 50 \% \mathrm{H}_{2} \mathrm{O} / \mathrm{H}_{2}$ & $\mathrm{Ni}$ & $\mathrm{Co}$ & $\mathrm{Fe}$ \\
\hline$\Delta_{\%} \mathrm{E}_{\mathrm{A}}$ & $14 \%$ & $53 \%$ & $25 \%$ \\
\hline$\Delta_{\%} \ln (\mathrm{A})$ & $27 \%$ & $76 \%$ & $9 \%$ \\
\hline Difference $\left(\left|\Delta_{\%} \ln (A)\right|-\left|\Delta_{\%} E_{A}\right|\right)$ & $13 \%$ & $23 \%$ & $-16 \%$ \\
\hline Correlation according to equation 3 and 8 & Power-law & Power-law & Invers power-law \\
\hline \multicolumn{3}{|l}{} \\
\hline $50 \% \mathrm{H}_{2} \mathrm{O} / \mathrm{H}_{2} \rightarrow 50 \% \mathrm{CO}_{2} / \mathrm{CO}$ & $\mathrm{Ni}$ & $\mathrm{Co}$ & $\mathrm{Fe}$ \\
\hline$\Delta_{\%} \mathrm{E}_{\mathrm{A}}$ & $12 \%$ & $-13 \%$ & $-17 \%$ \\
\hline$\Delta_{\%} \ln (\mathrm{A})$ & $9 \%$ & $-19 \%$ & $-28 \%$ \\
\hline Difference $\left(\left|\Delta_{\%} \ln (A)\right|-\left|\Delta_{\%} E_{A}\right|\right)$ & $-3 \%$ & $6 \%$ & $11 \%$ \\
\hline Correlation according to equation 3 and 8 & One to one & One to one & Power law \\
\hline
\end{tabular}




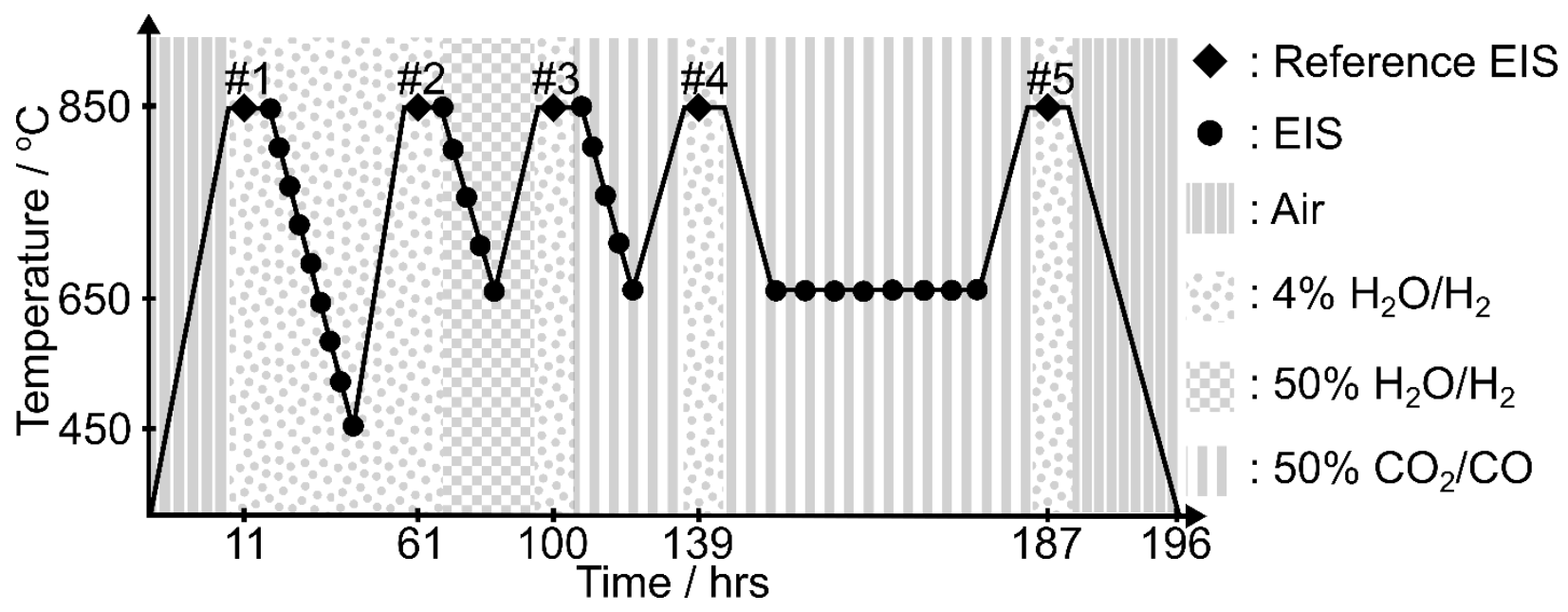

Figure 1: Schematic representation of the test protocol used for all cells in the present work. Black dots mark electrochemical impedance measurements performed during the test, and numbers with black diamonds state reference impedance measurements.
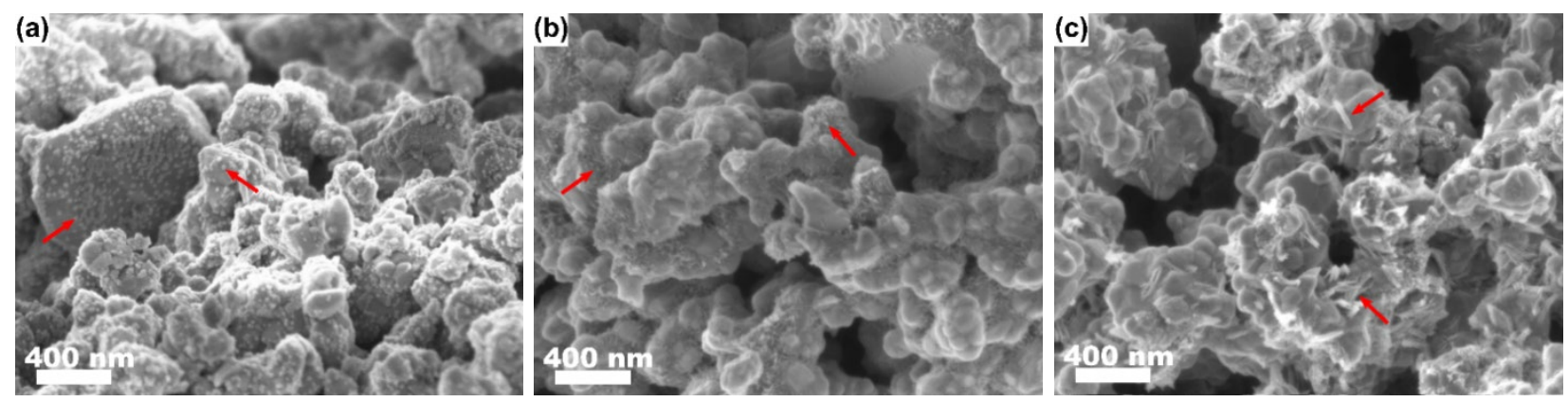

Figure 2: Infiltrated STN94 right after the infiltration procedure a) cobalt infiltrated sample with a spherical nanostructure b) iron infiltrated sample with a spherical nanostructure c) nickel infiltrated sample with a nanoneedle structure. Notice, examples of the infiltration structures are indicated with red arrows. 

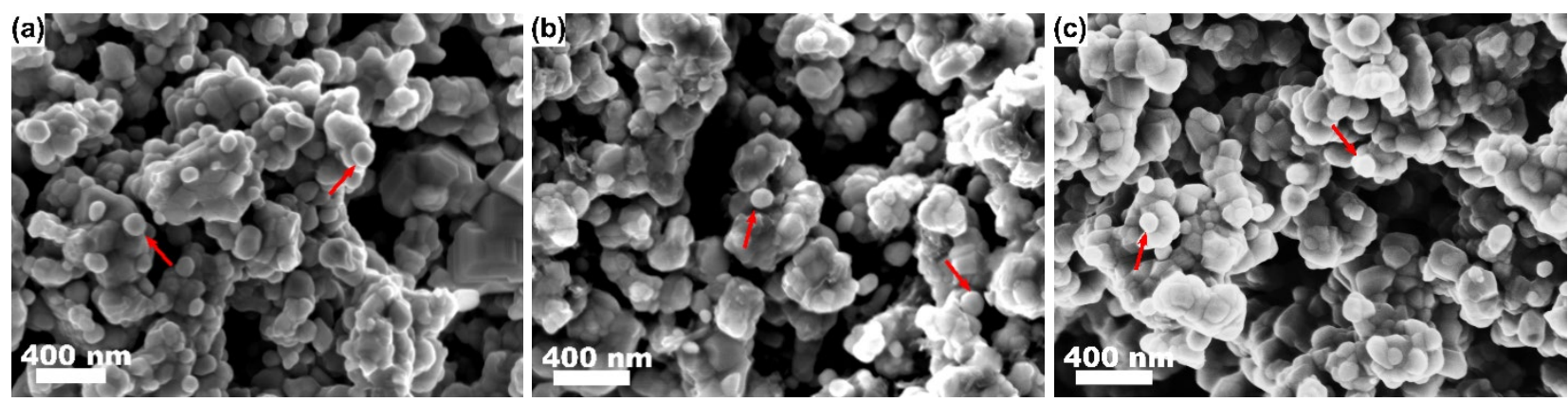

Figure 3: Infiltrated STN94 after the test procedure a) cobalt infiltrated sample b) iron infiltrated sample c) nickel infiltrated sample. Notice, that examples of the infiltration structures are indicated with red arrows.
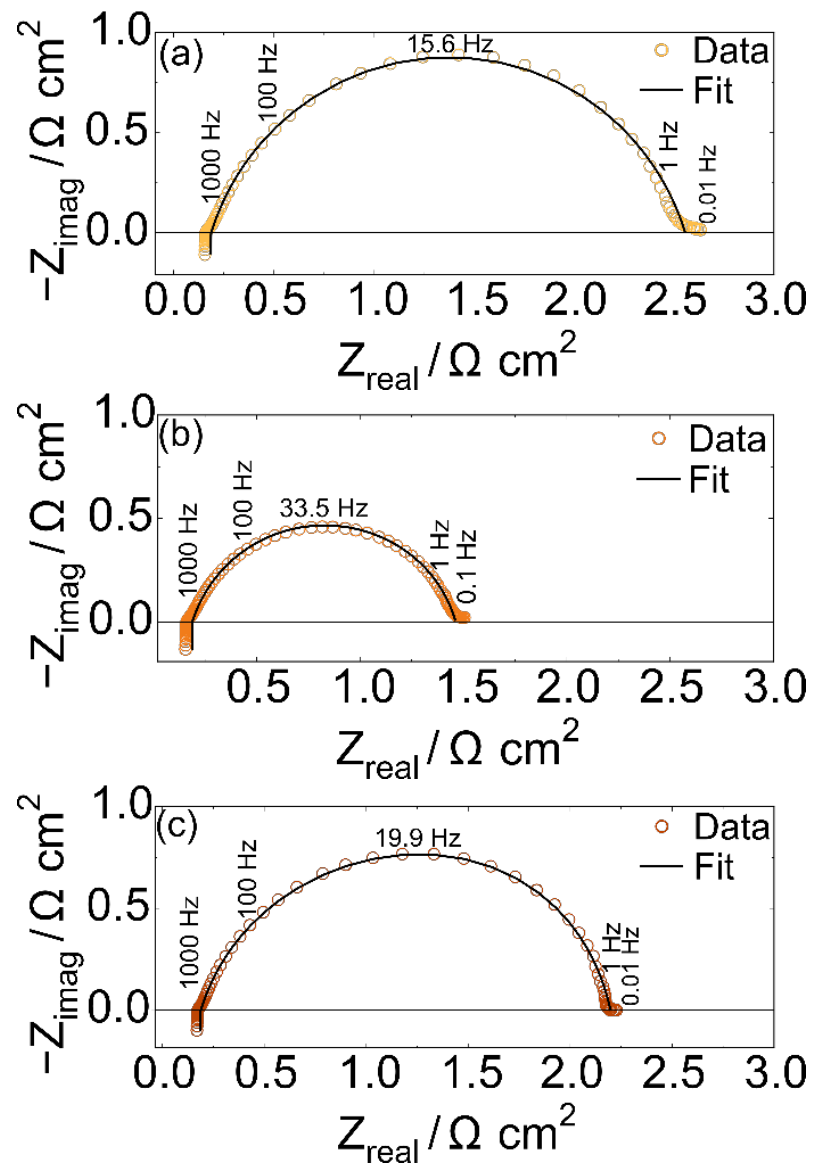

Figure 4: EIS data plot from a) cobalt, b) iron, and c) nickel infiltrated STN94 measured at $850^{\circ} \mathrm{C}$ in $4 \% \mathrm{H}_{2} \mathrm{O} / \mathrm{H}_{2}$, fitted with the equivalent circuit L-R-R $\mathrm{Q}_{1}-\mathrm{R}_{2} \mathrm{Q}_{2}$. 


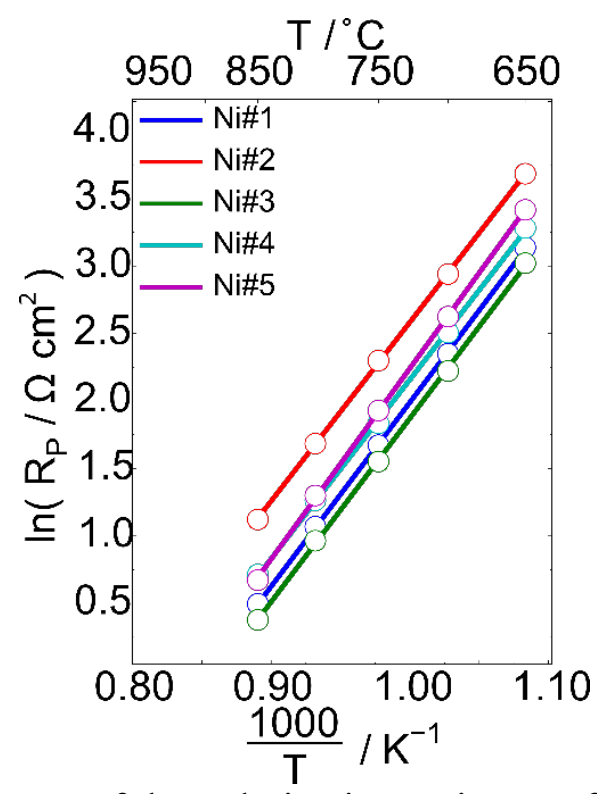

Figure 5: Temperature dependence of the polarization resistance for all nickel infiltrated samples measured in $4 \% \mathrm{H}_{2} \mathrm{O} / \mathrm{H}_{2}$. The lowest nickel content is found in $\mathrm{Ni \# 3}$ (green) with $0.54 \mathrm{mg} \cdot \mathrm{cm}^{-2}$

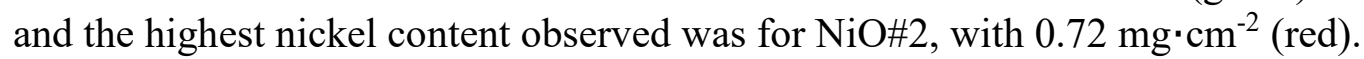

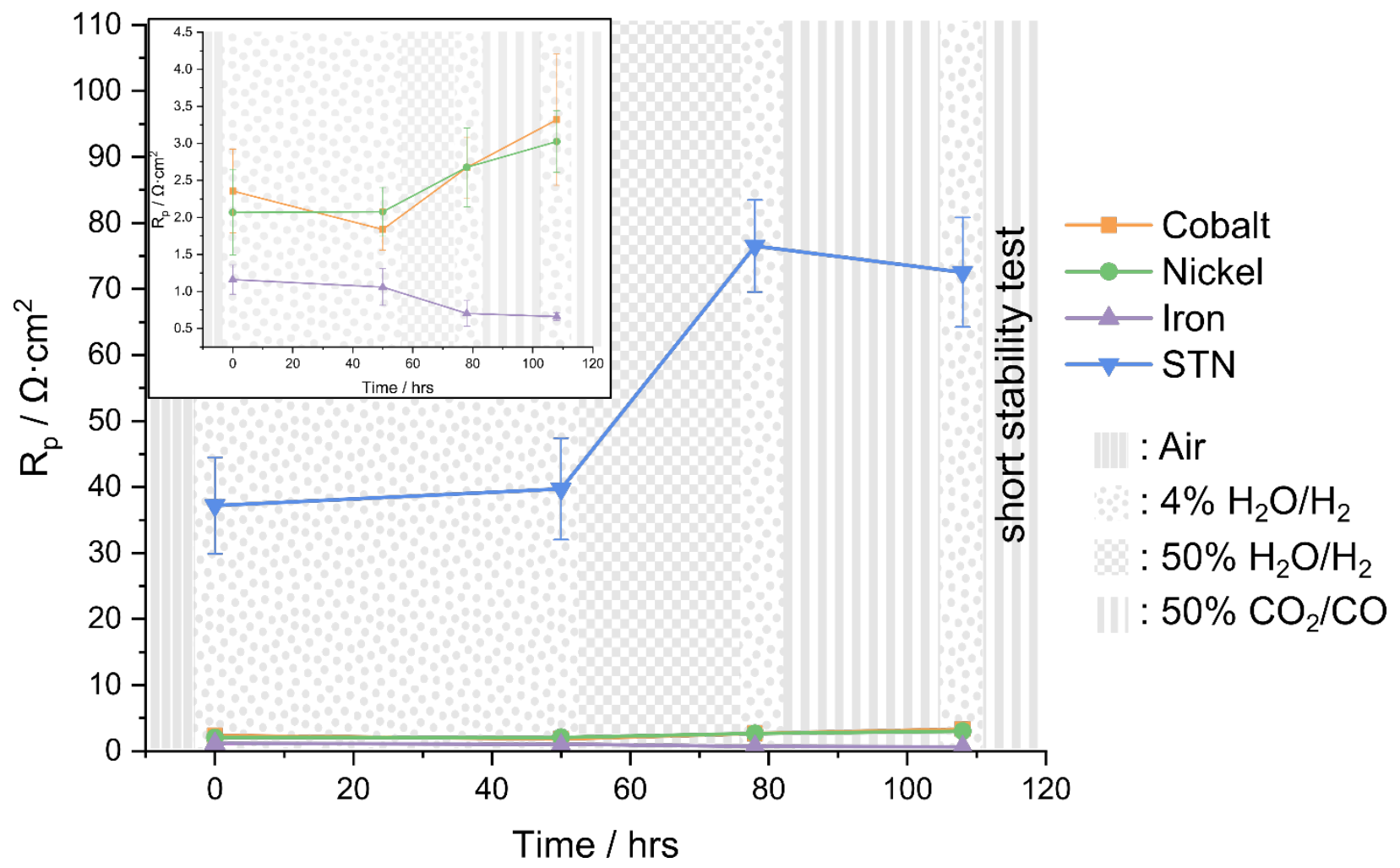

Figure 6: Polarization resistance measured in $\Omega \cdot \mathrm{cm}^{2}$ for the reference measurements conducted throughout the test 


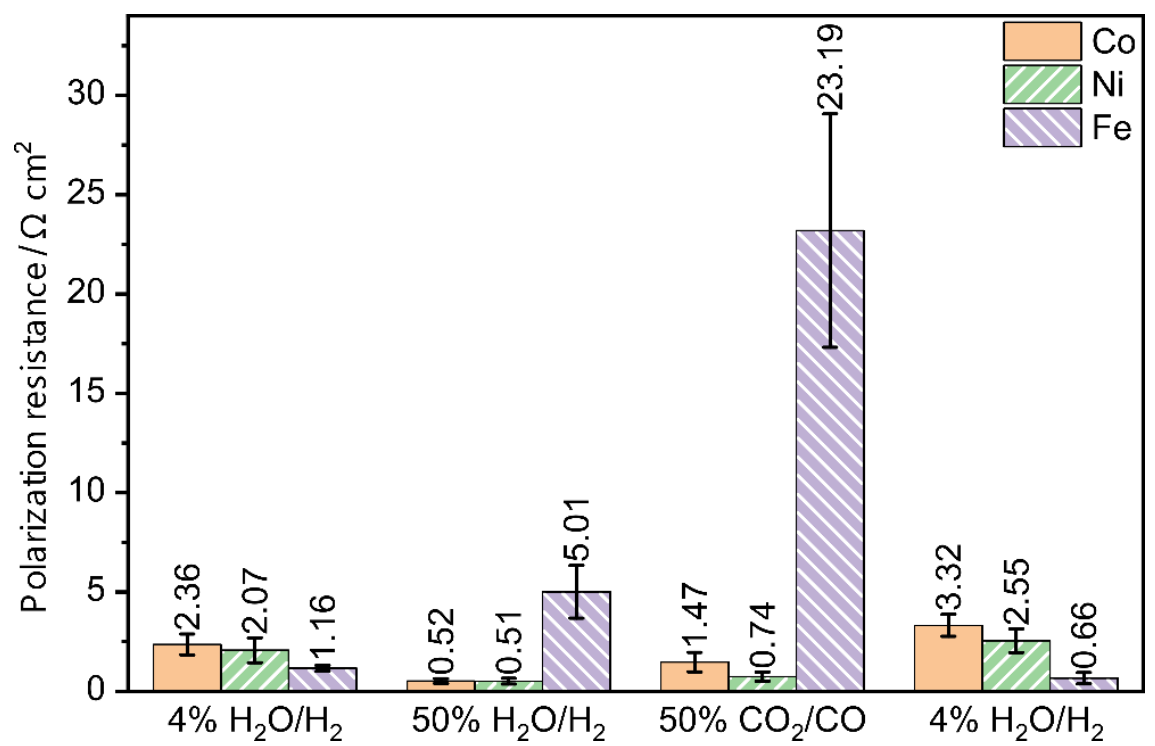

Figure 7: Polarization resistance measured in $\Omega \cdot \mathrm{cm}^{2}$ as a function of the atmosphere at $850^{\circ} \mathrm{C}$ for the different infiltrations.
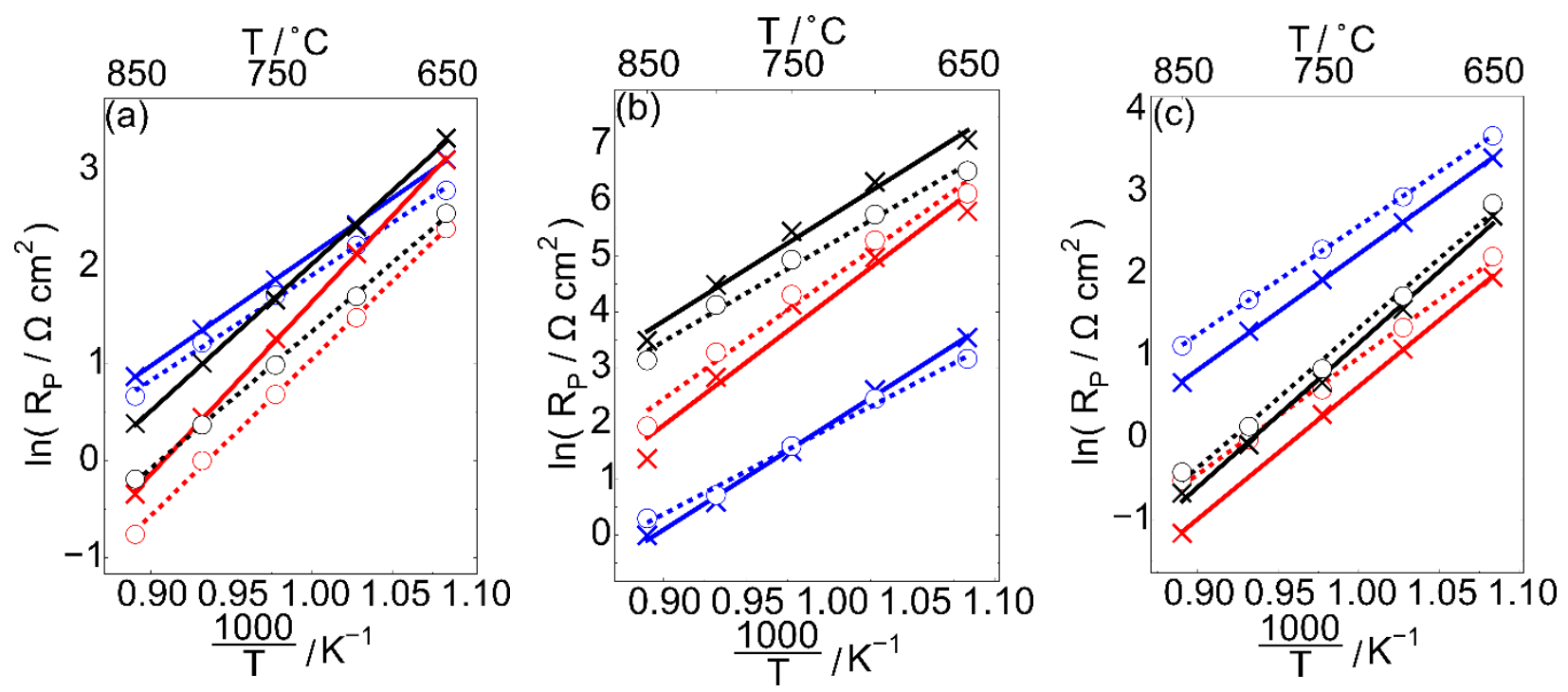

Figure 8: The highest (x) and lowest slope (o) values for the temperature dependence of the polarization resistance of a) cobalt infiltrations, b) iron infiltrations and c) nickel infiltrations in $4 \% \mathrm{H}_{2} \mathrm{O} / \mathrm{H}_{2}$ (blue), $50 \% \mathrm{H}_{2} \mathrm{O} / \mathrm{H}_{2}$ (red) and $50 \% \mathrm{CO}_{2} / \mathrm{CO}$ (black). 


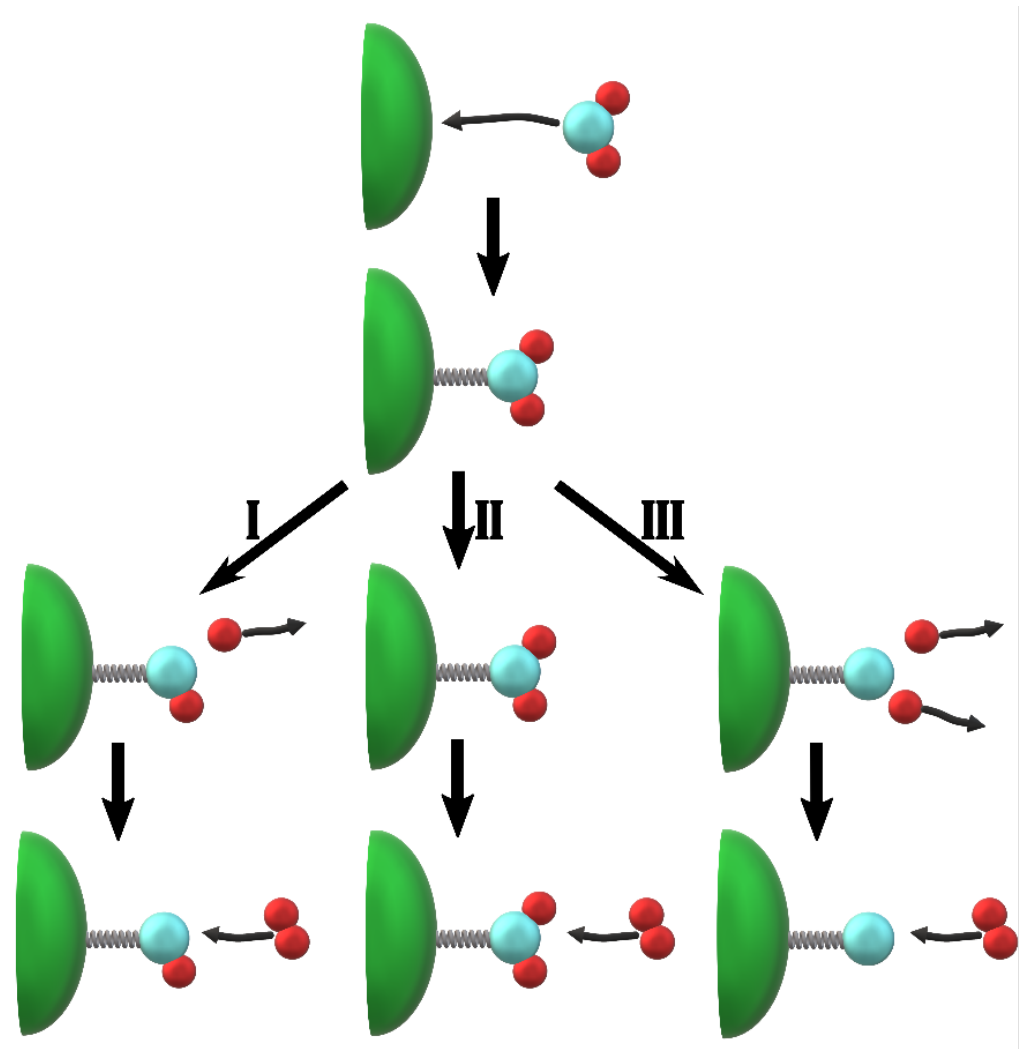

Figure 9: Schematic representation of three possible reaction mechanism for the blockade of catalytic sites on the iron nanoparticles. The green spheres represent the iron nanoparticle, the light blue represent oxygen atoms, and the red spheres represent hydrogen atoms 